\title{
Positive Homotropic Allosteric Binding of Benzenediols in a Hydrindacene-based Exoditopic Receptor: Cooperativity in Amide Hydrogen Bonding
}

\author{
Hidetoshi Kawai,* Ryo Katoono, Kouki Nishimura, Shunsuke Matsuda, \\ Kenshu Fujiwara, Takashi Tsuji,* and Takanori Suzuki \\ Division of Chemistry, Graduate School of Science, Hokkaido University, \\ Sapporo 060-0810, Japan \\ Fax: +81-11-706-2714, e-mail: kawai@ @ci.hokudai.ac.jp
}

\section{Supporting Information}

General: ${ }^{1} \mathrm{H}$ and ${ }^{13} \mathrm{C}$ NMR spectra were recorded on a JEOL ECP-300 $\left({ }^{1} \mathrm{H} / 300 \mathrm{MHz}\right.$, ${ }^{13} \mathrm{C} / 75 \mathrm{MHz}$ ) spectrometer in $\mathrm{CDCl}_{3}$ unless otherwise indicated. IR spectra were taken on a Hitachi Model 215 grating spectrometer. Mass spectra were recorded on JEOL JMS-DX300 (EI) and JMS-01SG-2 (FD) spectrometers. Column and thin-layer chromatography (TLC) were performed on silica gel 60 (Merck) of particle size 63-200 and 5-20 $\mu \mathrm{m}$, respectively. Elemental analyses were performed at the Center for Instrumental Analysis of Hokkaido University. 5-Chlororesorcinol $\mathbf{2} \mathbf{C l}^{1}$ and 1,4-Dibromo-2,3,5,6-tetrakis(bromomethyl)benzene $\mathbf{5}^{2}$ were prepared following the known procedures. Other reagents and solvents were obtained from commercial sources and purified prior to use.

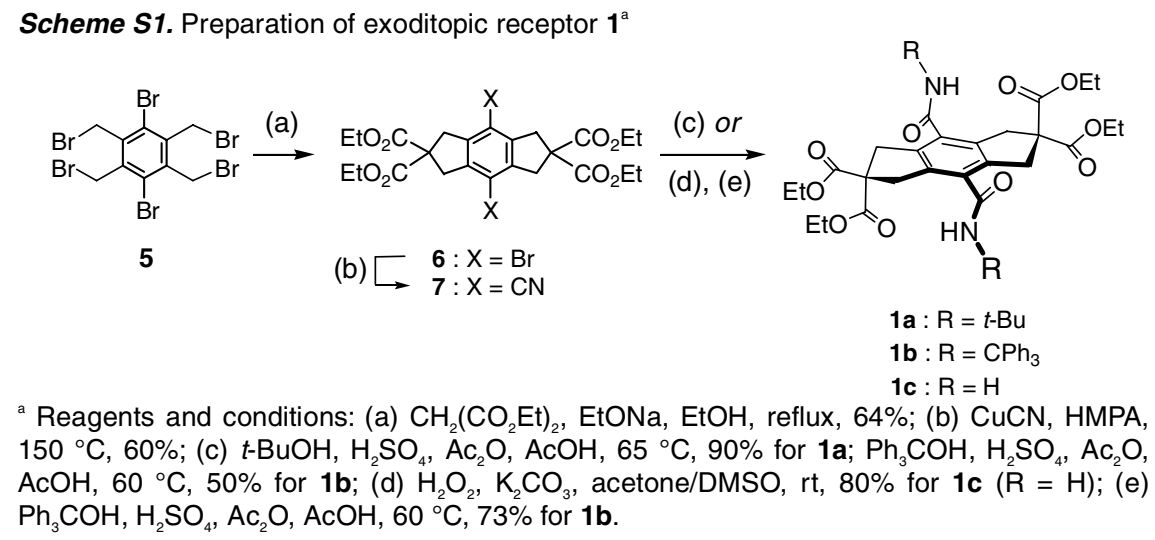

Preparation of Tetraethyl 4,8-Dibromo-1,2,3,5,6,7-hexahydro-s-indacene-2,2,6,6tetracarboxylate (6): To a sodium ethoxide solution, which was prepared by dissolving sodium metal $(14.2 \mathrm{~g}, 617 \mathrm{mmol})$ in absolute ethanol $(1.0 \mathrm{~L})$, were added diethyl 
malonate (49.1 g, $306 \mathrm{mmol})$ and then 1,4-dibromo-2,3,5,6-tetrakis(bromomethyl)benzene $\mathbf{5}^{2}(62.3 \mathrm{~g}, 103 \mathrm{mmol})$. After heating the reaction mixture with stirring at reflux for 7 $\mathrm{h}$ under $\mathrm{Ar}$, the solvent was removed under reduced pressure. The residue was neutralized with $0.5 \mathrm{M} \mathrm{HCl}(400 \mathrm{~mL})$ and extracted with $\mathrm{CHCl}_{3}(200 \mathrm{~mL} \times 3)$. The extracts were combined, dried over $\mathrm{MgSO}_{4}$, filtered, and the filtrate was concentrated under reduced pressure. The residue was recrystallized from $\mathrm{CHCl}_{3} / \mathrm{EtOH}$ (1:1) to give pure $6(39.7 \mathrm{~g}, 64 \%)$ as colorless crystals: $\mathrm{mp}$ 203.0-204.0 ${ }^{\circ} \mathrm{C} ;{ }^{1} \mathrm{H}$ NMR: $\delta 4.23(\mathrm{q}, J=$ $7.3 \mathrm{~Hz}, 8 \mathrm{H}), 3.64(\mathrm{~s}, 8 \mathrm{H}), 1.27(\mathrm{t}, J=7.3 \mathrm{~Hz}, 12 \mathrm{H}) ;{ }^{13} \mathrm{C} \mathrm{NMR}: \delta 170.97,140.60,114.78$, 62.03, 58.53, 42.44, 14.00; IR (KBr) 2984, 1736, 1446, 1282, 1246, 1160, 1072, 862, 802 $\mathrm{cm}^{-1}$; MS (FD) $m / z(\%): 602\left(\mathrm{M}^{+}, 48\right), 604\left(\mathrm{M}^{+}+2,100\right), 606\left(\mathrm{M}^{+}+2,56\right)$; Anal. Calcd. for $\mathrm{C}_{24} \mathrm{H}_{28} \mathrm{O}_{8} \mathrm{Br}_{2}$ : C, 47.70; H, 4.67; Found: C, 47.29; H, 4.63.

\section{Preparation of Tetraethyl 4,8-Dicyano-1,2,3,5,6,7-hexahydro-s-indacene-2,2,6,6-} tetracarboxylate (7): A mixture of $6(7.50 \mathrm{~g}, 12.4 \mathrm{mmol})$, copper(I) cyanide $(3.57 \mathrm{~g}$, $39.8 \mathrm{mmol})$, and hexamethylphosphoric triamide $(10 \mathrm{~mL})$ was heated with stirring at $150{ }^{\circ} \mathrm{C}$ for $8 \mathrm{~h}$ under $\mathrm{Ar}$, and then poured into an aqueous iron(III) chloride solution (10.8 $\mathrm{g}$, $40.1 \mathrm{mmol}$ in $\mathrm{H}_{2} \mathrm{O} 50 \mathrm{~mL}$ ) to decompose the complex. The resulting solid was separated from the liquid layer by filtration and washed successively with water, aqueous sodium hydrogen sulfite, and water. The residue was dissolved in chloroform and washed with an aqueous iron(III) chloride solution, water, and brine, and dried over $\mathrm{MgSO}_{4}$. The brown solid obtained by evaporation of the solvent was subjected to chromatography on silica gel eluted with chloroform. The resulting yellow solid (4.38 g) was recrystallized from $\mathrm{CHCl}_{3} / \mathrm{EtOH}(1: 2)$ to give pure $7(3.77 \mathrm{~g}, 60 \%)$ as colorless crystals: $\mathrm{mp}$ 196.5-198.0 ${ }^{\circ} \mathrm{C} ;{ }^{1} \mathrm{H}$ NMR: $\delta 4.24(\mathrm{q}, J=7.2 \mathrm{~Hz}, 8 \mathrm{H}), 3.75(\mathrm{~s}, 8 \mathrm{H}), 1.28(\mathrm{t}, J=7.2 \mathrm{~Hz}$, 12H); ${ }^{13} \mathrm{C}$ NMR: $\delta 170.12,144.31,114.63,109.06,62.47,59.61,39.87,13.97$; IR (KBr) 2984, 2228, 1732, 1304, 1250, 1192, 1074, $858 \mathrm{~cm}^{-1}$; MS (FD) $\mathrm{m} / z(\%): 496\left(\mathrm{M}^{+}, 100\right)$; Anal. Calcd. for $\mathrm{C}_{26} \mathrm{H}_{28} \mathrm{~N}_{2} \mathrm{O}_{8}: \mathrm{C}, 62.90 ; \mathrm{H}, 5.68 ; \mathrm{N}, 5.64$. Found: C, 62.63; H, 5.55; N, 5.58 .

\section{Preparation of Tetraethyl 4,8-Bis(t-butylcarbamoyl)-1,2,3,5,6,7-hexahydro-s-} indacene-2,2,6,6-tetracarboxylate (1a): To a mixture of 7 (200 mg, $0.40 \mathrm{mmol}$ ), $t$-butanol (386 $\mu \mathrm{L}, 4.0 \mathrm{mmol})$, acetic anhydride $(380 \mu \mathrm{L}, 4.0 \mathrm{mmol})$, and acetic acid (5.0 mL) was added $\mathrm{H}_{2} \mathrm{SO}_{4}(54 \mu \mathrm{L}, 1.0 \mathrm{mmol})$. After stirring at $65^{\circ} \mathrm{C}$ for $20 \mathrm{~h}$, the reaction 
mixture was poured slowly into $5 \%$ aqueous $\mathrm{NaHCO}_{3}$. The resulting suspension was extracted with EtOAc. The organic layer was washed with $5 \%$ aqueous $\mathrm{NaHCO}_{3}$, water and brine, dried over $\mathrm{MgSO}_{4}$, and then filtered. The white solid obtained by concentrating the filtrate was subjected to chromatography on silica gel eluted with EtOAc/hexane (4:6). The resulting white solid was recrystallized from EtOH to give pure 1a (233 $\mathrm{mg}, 90 \%)$ as colorless crystals: mp 242.0-242.5 ${ }^{\circ} \mathrm{C} ;{ }^{1} \mathrm{H}$ NMR: $\delta 5.56(\mathrm{~s}, 2 \mathrm{H}), 4.20(\mathrm{q}, J=7.2 \mathrm{~Hz}, 8 \mathrm{H})$, $3.59(\mathrm{~s}, 8 \mathrm{H}), 1.48(\mathrm{~s}, 18 \mathrm{H}), 1.25(\mathrm{t}, J=7.2 \mathrm{~Hz}, 12 \mathrm{H}) ;{ }^{13} \mathrm{C}$ NMR: $\delta 171.20,166.76,137.54$, 131.35, 61.94, 60.52, 52.06, 39.14, 28.96, 14.01; IR (KBr) 3384, 2988, 1732, 1668, 1534, 1276, 1078, $860 \mathrm{~cm}^{-1}$; MS (FD) m/z (\%): $644\left(\mathrm{M}^{+}\right.$, 100); Anal. Calcd. for $\mathrm{C}_{34} \mathrm{H}_{48} \mathrm{~N}_{2} \mathrm{O}_{10}$ : C, 63.34; H, 7.50; N, 4.34. Found: C, 63.17; H, 7.62; N, 4.33.

\section{Preparation of Tetraethyl 4,8-Bis(tritylcarbamoyl)-1,2,3,5,6,7-hexahydro-s-indacene} -2,2,6,6-tetracarboxylate (1b), Method A: To a mixture of 7 (200 mg, $0.40 \mathrm{mmol}$ ), triphenylmethanol $(629 \mathrm{mg}, 2.42 \mathrm{mmol})$, acetic anhydride $(114 \mu \mathrm{L}, 1.21 \mathrm{mmol})$, and acetic acid $(5.0 \mathrm{~mL})$ was added $\mathrm{H}_{2} \mathrm{SO}_{4}(43 \mu \mathrm{L}, 0.81 \mathrm{mmol})$. After stirring at $60{ }^{\circ} \mathrm{C}$ for 12 $\mathrm{h}$, the reaction mixture was poured slowly into $5 \%$ aqueous $\mathrm{NaHCO}_{3}$. The resulting suspension was extracted with EtOAc, and the organic layer was washed with 5\% aqueous $\mathrm{NaHCO}_{3}$, water and brine, dried over $\mathrm{MgSO}_{4}$, and then filtered. The white solid obtained by concentrating the filtrate was subjected to chromatography on silica gel eluted with $\mathrm{CHCl}_{3} /$ hexane (7:3). The resulting white solid was recrystallized from benzene to give $\mathbf{1 b \bullet ( b e n z e n e )})_{2}(235 \mathrm{mg}, 50 \%)$ as colorless crystals. Desolvated $\mathbf{1 b}$ was obtained by heating $\mathbf{1 b} \bullet(\text { benzene })_{2}$ at $80^{\circ} \mathrm{C}$ in vacuo $(0.1 \mathrm{mmHg})$. Analytical sample was obtained by recrystallization from $\mathrm{CHCl}_{3}$ /ether.

Method B: To a solution of 7 (555 $\mathrm{mg}, 1.12 \mathrm{mmol})$ in acetone/DMSO (1:1, $100 \mathrm{~mL})$ were added successively $30 \%$ aqueous $\mathrm{H}_{2} \mathrm{O}_{2}(10 \mathrm{~mL})$ and $\mathrm{K}_{2} \mathrm{CO}_{3}(250 \mathrm{mg}, 1.81 \mathrm{mmol})$ at $0{ }^{\circ} \mathrm{C}$. The reaction mixture was allowed to warm to $20{ }^{\circ} \mathrm{C}$ and stirred for $48 \mathrm{~h}$. After evaporating of acetone, $0.1 \mathrm{M} \mathrm{HCl}(200 \mathrm{~mL})$ was added and the resulting suspension was filtered to obtain a solid. The resulting white solid was washed with water and dried in vacuo to give primary amide 1c $(477 \mathrm{mg}, 80 \%)$ : $\mathrm{mp} 261-263^{\circ} \mathrm{C} \mathrm{dec}$; ${ }^{1} \mathrm{H} \mathrm{NMR}$ $\left(\left(\mathrm{CD}_{3}\right)_{2} \mathrm{CO}\right): \delta 7.04(\mathrm{~s}, 2 \mathrm{H}), 6.90(\mathrm{~s}, 2 \mathrm{H}), 4.18(\mathrm{q}, J=7.2 \mathrm{~Hz}, 8 \mathrm{H}), 3.66(\mathrm{~s}, 8 \mathrm{H}), 1.22(\mathrm{t}, J$ $=7.2 \mathrm{~Hz}, 12 \mathrm{H})$; IR (KBr) 3372, 3188, 2928, 1734, 1658, 1390, 1282, 1248, 1192, 1068, 860, $688 \mathrm{~cm}^{-1}$; MS (FD) $\mathrm{m} / z(\%): 532\left(\mathrm{M}^{+}, 100\right)$; Anal. Calcd. for $\mathrm{C}_{26} \mathrm{H}_{34} \mathrm{~N}_{2} \mathrm{O}_{10}$ : C, 58.42; H, 6.41; N, 5.24. Found: C, 58.27; H, 6.17; N, 5.16. 
To a mixture of the above amide 1c $(200 \mathrm{mg}, 0.38 \mathrm{mmol})$, triphenylmethanol (391 $\mathrm{mg}$, $1.50 \mathrm{mmol})$, acetic anhydride $(142 \mu \mathrm{L}, 1.50 \mathrm{mmol})$, and acetic acid $(5.0 \mathrm{~mL})$ was added $\mathrm{H}_{2} \mathrm{SO}_{4}(42 \mu \mathrm{L}, 0.79 \mathrm{mmol})$. After stirring at $60{ }^{\circ} \mathrm{C}$ for $2.5 \mathrm{~h}$, the reaction mixture was worked up as described in the method A to produce 1b (280 mg, 73\%): $\mathrm{mp}$ 244.5-245.0 ${ }^{\circ} \mathrm{C} ;{ }^{1} \mathrm{H}$ NMR: $\delta$ 7.36-7.25 (m, 30H), $6.89(\mathrm{~s}, 2 \mathrm{H}), 4.16(\mathrm{q}, J=7.1 \mathrm{~Hz}, 8 \mathrm{H})$, $3.59(\mathrm{~s}, 8 \mathrm{H}), 1.23(\mathrm{t}, J=7.1 \mathrm{~Hz}, 12 \mathrm{H}) ;{ }^{13} \mathrm{C}$ NMR: $\delta 170.93,166.38,144.40,138.36$, 131.02, 128.73, 128.10, 127.22, 71.39, 61.84, 60.60, 39.58, 14.03; IR (KBr) 3412, 2928, 1730, 1684, 1492, 1282, 1240, 1070, 752, $700 \mathrm{~cm}^{-1}$; MS (FD) $\mathrm{m} / z(\%): 1016\left(\mathrm{M}^{+}, 100\right)$; Anal. Calcd. for $\mathrm{C}_{64} \mathrm{H}_{60} \mathrm{~N}_{2} \mathrm{O}_{10}$ : C, 75.57; H, 5.95; N, 2.75. Found: C, 75.72; H, 6.07; N, 2.48 .

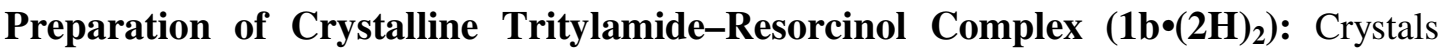
suitable for crystallography were obtained by slow vapor diffusion of hexane into a solution of 1b and $2 \mathbf{H}$ (1:10) in $\mathrm{CHCl}_{3} /$ ether. mp 213-215 ${ }^{\circ} \mathrm{C}$; IR (KBr) 3380, 2984, 1714, 1640, 1604, 1494, 1370, 1298, 1244, 1072, 832, 750, 702, $628 \mathrm{~cm}^{-1}$; Anal. Calcd. for $\mathrm{C}_{76} \mathrm{H}_{72} \mathrm{~N}_{2} \mathrm{O}_{14}$ : C, 73.77; H, 5.86; N, 2.26. Found: C, 73.77; H, 6.03; N, 2.26.

${ }^{1} \mathbf{H}$ NMR Titrations: A sample of receptor $\mathbf{1 a}$ or $\mathbf{1 b}$ was dissolved in $\mathrm{CDCl}_{3}$ to give a solution with a concentration range of $1-4 \mathrm{mM}$. A portion $(0.5 \mathrm{~mL})$ of this solution was used as the host NMR sample, and the remainder was used to dissolve a sample of the guest 2 $\mathbf{- 4}$, so that the receptor concentration remains constant throughout the titration. Successive aliquots of the guest solution were added to the host NMR sample, and ${ }^{1} \mathrm{H}$ NMR spectra were recorded after each addition at $298 \mathrm{~K}$. The changes in chemical shift of all of the receptor signals as a function of guest concentration were then analyzed with a purpose-written software NMRTit HGG for the 1:2 complexation, kindly provided by Professor C. A. Hunter ${ }^{3}$. Titration data for two \pm four different signals were used to determine the association constant in each experiment. Errors are quoted as twice the standard error from the weighted mean (weighting based on the observed change in chemical shift).

Job Plots: For each component of the complex, $5 \mathrm{~mL}$ solutions of accurately measured and identical concentrations (in the range 3-5 $\mathrm{mM}$ ) were prepared. The two solutions were then combined to give a series of samples of identical total concentration but containing different mole fractions $(\chi)$ of the two components. The ${ }^{1} \mathrm{H}$ NMR spectrum of each sample was then recorded, and these spectra were used to produce a graph of $(\Delta \delta \times \chi)$ against $\chi$ shown as the Job plot $\left(\Delta \delta=\Delta \delta_{\text {observed }}-\Delta \delta_{\chi=1.0}\right)^{4}$ 


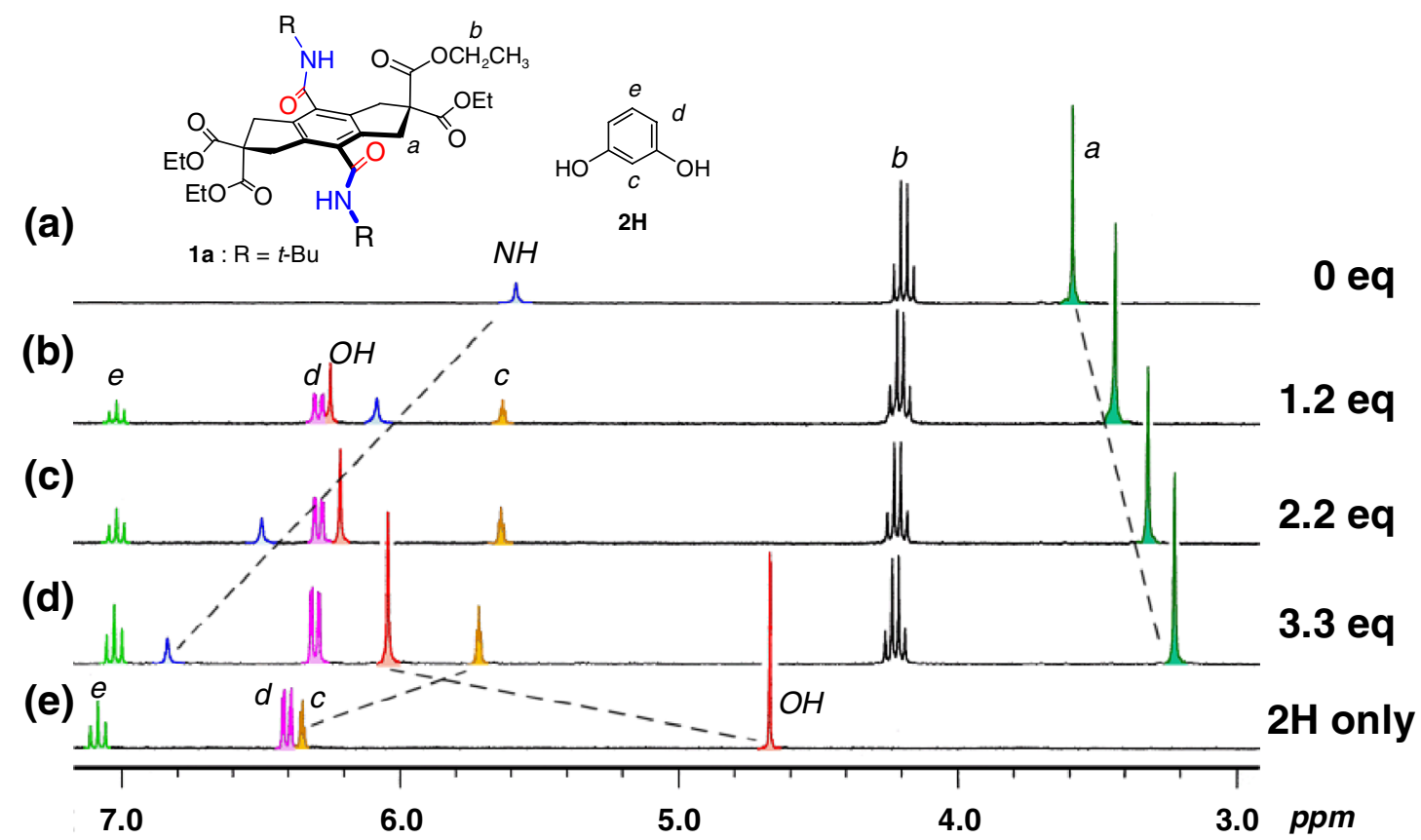

Figure S1. Complexation of receptor 1 with $\mathbf{2} \mathbf{H}$. ${ }^{1} \mathrm{H}$ NMR spectra $\left(300 \mathrm{MHz}, \mathrm{CDCl}_{3}\right)$ from a titration experiment of $1 \mathrm{a}$ with equivalents of $\mathbf{2 H}$ added indicated on the right of the spectra. (a) Receptor 1a. (b) 1.2 equiv, (c) 2.2 equiv, and (d) 3.3 equiv of $\mathbf{2 H}$ was added. (e) Guest $\mathbf{2 H}$.

X-ray Analyses: Crystal data for 1a: Crystals were obtained by recrystallizing from EtOH. $\mathrm{C}_{34} \mathrm{H}_{48} \mathrm{~N}_{2} \mathrm{O}_{10}, M 644.75$, colorless block, $0.5 \times 0.4 \times 0.4 \mathrm{~mm}^{3}$, monoclinic $P 2{ }_{1} / \mathrm{c}, a=$ 8.287(3) $\mathrm{\AA}, b=20.037(8) \AA, c=10.151(4) \AA, \beta=95.856(6)^{\circ}, V=1676(1) \AA^{3}, \rho(Z=2)$ $=1.277 \mathrm{~g} \mathrm{~cm}^{-1}$. A total of 3779 unique data $\left(2 \theta_{\max }=55^{\circ}\right)$ were measured at $T=153 \mathrm{~K}$ by a Rigaku Mercury CCD apparatus (Mo K $\alpha$ radiation, $\lambda=0.71069 \AA ̊$ ). Numerical absorption correction was applied $\left(\mu=0.94 \mathrm{~cm}^{-1}\right)$. The structure was solved by the direct method (SIR92) and refined by the full-matrix least-squares method on $F$ with anisotropic temperature factors for non-hydrogen atoms. All the hydrogen atoms were located in the D map and refined with isotropic temperature factors. The final $R$ and $R w$ values are 0.037 and 0.048 for 2539 reflections with $I>3 \sigma$ and 208 parameters. Estimated standard deviations are $0.002 \AA$ for bond lengths and $0.1^{\circ}$ for bond angles, respectively.

Crystal data for $\mathbf{1 b}$ : Crystals were obtained by slow vapor diffusion of hexane into a solution of $\mathbf{1 b}$ in ether. $\mathrm{C}_{64} \mathrm{H}_{60} \mathrm{~N}_{2} \mathrm{O}_{10}, M 1017.17$, colorless block, $0.35 \times 0.15 \times 0.1 \mathrm{~mm}^{3}$, monoclinic $P 2{ }_{1} / \mathrm{n}, a=8.337(3) \AA, b=19.963(7) \AA, c=15.750(6) \AA, \beta=102.408(7)^{\circ}, V$ $=2559(1) \AA^{3}, \rho(Z=2)=1.320 \mathrm{~g} \mathrm{~cm}^{-1}$. A total of 5652 unique data $\left(2 \theta_{\max }=55^{\circ}\right)$ were measured at $T=173 \mathrm{~K}$ by a Rigaku Mercury $\mathrm{CCD}$ apparatus (Mo $\mathrm{K} \alpha$ radiation, $\lambda=$ 
$0.71069 \AA)$. Numerical absorption correction was applied $\left(\mu=0.89 \mathrm{~cm}^{-1}\right)$. The structure was solved by the direct method (SIR92) and refined by the full-matrix least-squares method on $F$ with anisotropic temperature factors for non-hydrogen atoms. All the hydrogen atoms were located in the D map and refined with isotropic temperature factors. The final $R$ and $R w$ values are 0.048 and 0.055 for 2765 reflections with $I>3 \sigma$ and 343 parameters. Estimated standard deviations are 0.003-0.004 $\AA$ for bond lengths and $0.2-0.3^{\circ}$ for bond angles, respectively.

Crystal data for $\mathbf{1 b} \bullet(\mathbf{2 H})_{2}$ : Crystals were obtained by the procedure described above. $\mathrm{C}_{64} \mathrm{H}_{60} \mathrm{~N}_{2} \mathrm{O}_{10} \bullet\left(\mathrm{C}_{6} \mathrm{H}_{6} \mathrm{O}_{2}\right)_{2}, M 1237.41$, colorless block, $0.3 \times 0.3 \times 0.15 \mathrm{~mm}^{3}$, monoclinic $P 2_{1} / \mathrm{c}, a=13.343(2) \AA, b=13.7657(7) \AA, c=18.3825(6) \AA, \beta=111.5078(7)^{\circ}, V=$ $3141.2(5) \AA^{3}, \rho(Z=2)=1.308 \mathrm{~g} \mathrm{~cm}^{-1}$. A total of 7205 unique data $\left(2 \theta_{\max }=55^{\circ}\right)$ were measured at $T=110 \mathrm{~K}$ by a Rigaku Mercury $\mathrm{CCD}$ apparatus (Mo K $\alpha$ radiation, $\lambda=$ $0.71069 \AA)$. Numerical absorption correction was applied $\left(\mu=0.90 \mathrm{~cm}^{-1}\right)$. The structure was solved by the direct method (SIR92) and refined by the full-matrix least-squares method on $F$ with anisotropic temperature factors for non-hydrogen atoms. All the hydrogen atoms were located in the D map and refined with isotropic temperature factors. The final $R$ and $R w$ values are 0.054 and 0.073 for 4973 reflections with $I>3 \sigma$ and 415 parameters. Estimated standard deviations are 0.002-0.003 $\AA$ for bond lengths and 0.1-0.3 for bond angles, respectively.

Crystal data for $\mathbf{1 b} \cdot(\mathbf{3})_{2}$ : Crystals were obtained by slow vapor diffusion of hexane into a solution of $\mathbf{1 b}$ and 3 in $\mathrm{CHCl}_{3}$ /ether. $\mathrm{C}_{64} \mathrm{H}_{60} \mathrm{~N}_{2} \mathrm{O}_{10} \bullet\left(\mathrm{C}_{6} \mathrm{H}_{6} \mathrm{O}_{2}\right)_{2}, M$ 1237.41, colorless rod, 0.4 $\times 0.2 \times 0.2 \mathrm{~mm}^{3}$, monoclinic $P-1, a=11.4515(9) \AA, b=12.187(1) \AA, c=12.550(1) \AA$, $\alpha=85.201(3)^{\circ}, \beta=79.058(2)^{\circ}, \gamma=69.252(1)^{\circ}, V=1607.9(3) \AA^{3}, \rho(Z=1)=1.278 \mathrm{~g}$ $\mathrm{cm}^{-1}$. A total of 6530 unique data $\left(2 \theta_{\max }=55^{\circ}\right)$ were measured at $T=173 \mathrm{~K}$ by a Rigaku Mercury CCD apparatus (Mo K $\alpha$ radiation, $\lambda=0.71069 \AA$ ). Numerical absorption correction was applied $\left(\mu=0.88 \mathrm{~cm}^{-1}\right)$. The structure was solved by the direct method (SIR92) and refined by the full-matrix least-squares method on $F$ with anisotropic temperature factors for non-hydrogen atoms. All the hydrogen atoms were located in the $\mathrm{D}$ map and refined with isotropic temperature factors. The final $R$ and $R w$ values are 0.055 and 0.077 for 4262 reflections with $I>3 \sigma$ and 424 parameters. Estimated standard deviations are $0.002-0.005 \AA$ for bond lengths and $0.1-0.3^{\circ}$ for bond angles, respectively. Crystal data for $\mathbf{1 b \bullet a c e t o n e : ~ C r y s t a l s ~ w e r e ~ o b t a i n e d ~ b y ~ s l o w ~ v a p o r ~ d i f f u s i o n ~ o f ~ h e x a n e ~ i n t o ~ a ~}$ 
solution of $1 \mathbf{b}$ in acetone. $\mathrm{C}_{64} \mathrm{H}_{60} \mathrm{~N}_{2} \mathrm{O}_{10}{ }^{\circ} \mathrm{C}_{3} \mathrm{H}_{6} \mathrm{O}, M 1075.27$, colorless plate, $0.40 \times 0.20 \times$ $0.05 \mathrm{~mm}^{3}$, monoclinic $P-1, a=8.889(1) \AA, b=17.022(1) \AA, c=19.613(3) \AA, \alpha=$ $80.493(3)^{\circ}, \beta=84.133(1)^{\circ}, \gamma=77.093(1)^{\circ}, V=2846.5(7) \AA^{3}, \rho(Z=2)=1.254 \mathrm{~g} \mathrm{~cm}^{-1} . \mathrm{A}$ total of 11509 unique data $\left(2 \theta_{\max }=55^{\circ}\right)$ were measured at $T=123 \mathrm{~K}$ by a Rigaku Mercury CCD apparatus (Mo K $\alpha$ radiation, $\lambda=0.71069 \AA$ ). Numerical absorption correction was applied $\left(\mu=0.083 \mathrm{~cm}^{-1}\right)$. The structure was solved by the direct method (SIR92) and refined by the full-matrix least-squares method on $F$ with anisotropic temperature factors for non-hydrogen atoms. All the hydrogen atoms were located in the $\mathrm{D}$ map and refined with isotropic temperature factors. The final $R$ and $R w$ values are 0.049 and 0.061 for 6953 reflections with $I>3 \sigma$ and 721 parameters. Estimated standard deviations are $0.003-0.004 \AA$ for bond lengths and $0.2-0.3^{\circ}$ for bond angles, respectively.

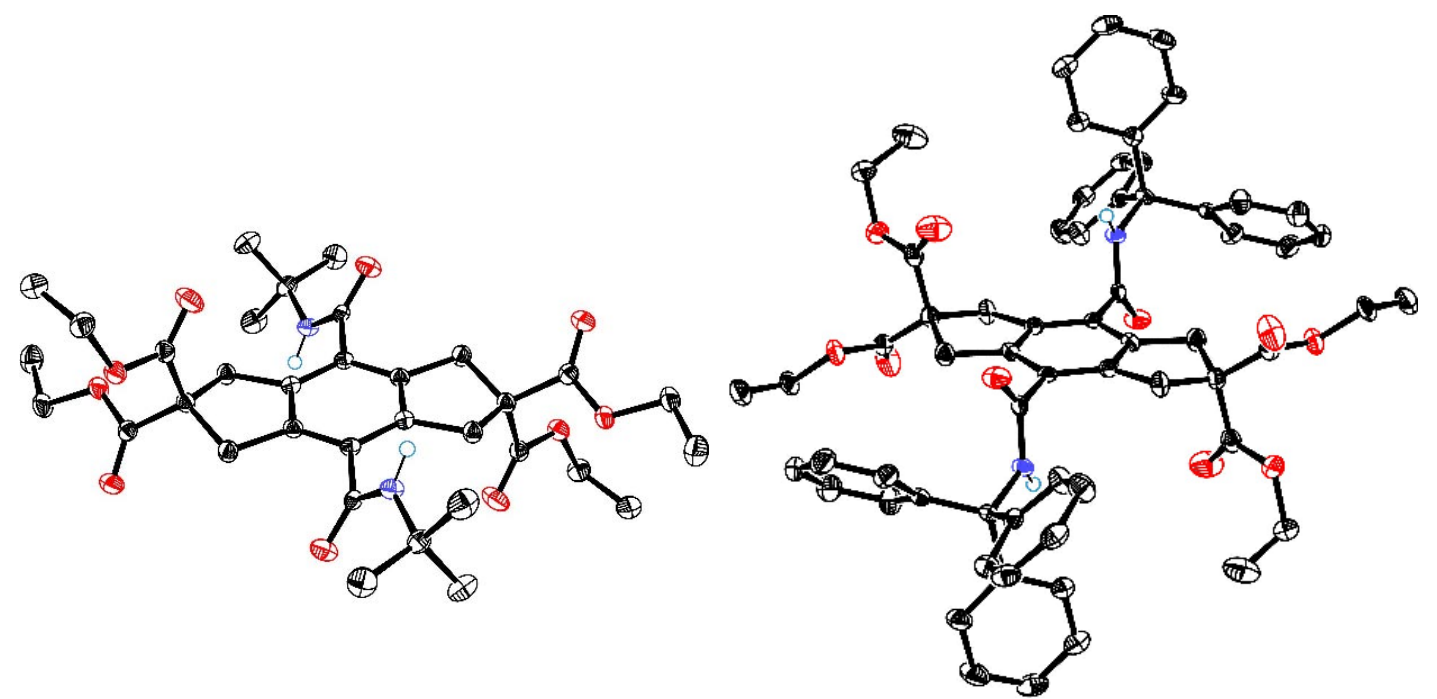

$1 \mathbf{a}$

$1 \mathrm{~b}$

Figure S2. X-ray crystal structures of complex 1a (left) and $\mathbf{1 b}$ (right). ORTEP representation with $50 \%$ probability. Hydrogen atoms except amide $\mathrm{NH}$ are omitted for clarity.

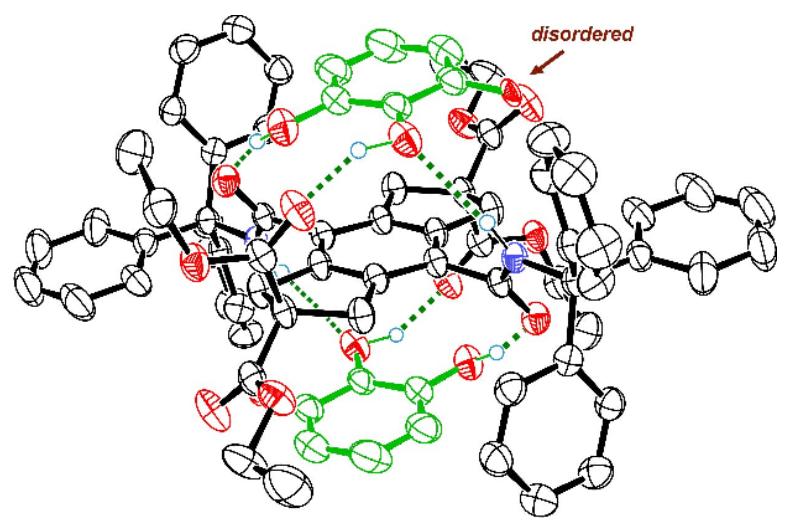

Figure S3. X-ray crystal structure of complex $\mathbf{1 b} \bullet(\mathbf{3})_{2}$. ORTEP representation with $50 \%$ probability. Hydrogen atoms not involved in hydrogen bonds are omitted for clarity. 


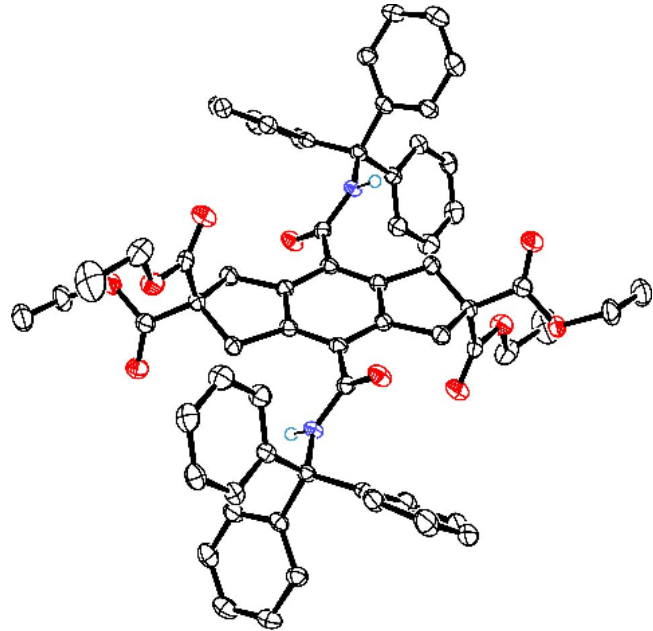

molecule A (free 1b)

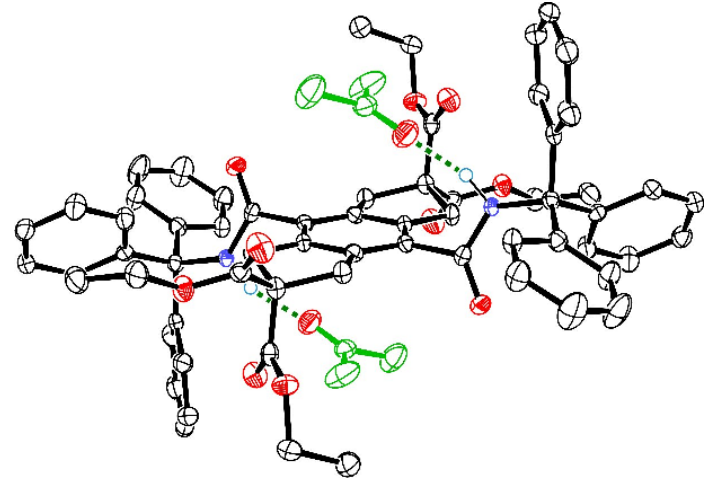

molecule B (1b•(acetone $\left.)_{2}\right)$

Figure S4. X-ray crystal structures of $\mathbf{1 b} \cdot a c e t o n e ~ s o l v a t e$, which contains two independent molecules $\mathbf{A}$ (left) and $\mathbf{B}$ (right). ORTEP representation with 50\% probability. Hydrogen atoms except amide NH are omitted for clarity.

Table S1. Hydrogen Bonding Partners $\boldsymbol{D}$ and $\boldsymbol{A}$ with Amide Groups, Amide Bond Lengths $R(\AA)$, and Rotation Angles $\phi\left({ }^{\circ}\right)$ toward Aromatic Plane in Crystals.

\begin{tabular}{|c|c|c|c|c|c|}
\hline & & $1 b^{a}$ & $\begin{array}{c}\mathbf{1 \mathbf { b } ^ { \mathrm { b } }} \\
(\text { molecule } \mathbf{A})\end{array}$ & $\begin{array}{c}\mathbf{1 b} \cdot(\text { acetone })_{2}^{\mathrm{b}} \\
(\text { molecule } \mathbf{B})\end{array}$ & $\mathbf{1 b} \cdot(\mathbf{2 H})_{2}$ \\
\hline & $D$ & - & - & - & $\mathrm{ArO}-H$ \\
\hline & $A$ & - & - & $\left(\mathrm{CH}_{3}\right)_{2} \mathrm{C}=\mathrm{O}$ & $\mathrm{Ar}-O-\mathrm{H}$ \\
\hline & $R_{\mathrm{C}-\mathrm{N}}$ & $1.366(3)$ & $1.360(3)$ & $1.343(3)$ & $1.342(2)$ \\
\hline & $R_{\mathrm{C}=\mathrm{O}}$ & $1.217(3)$ & $1.224(3)$ & $1.227(3)$ & $1.232(2)$ \\
\hline Dี & $\phi$ & 78.1 & 44.7 & 72.9 & 83.5 \\
\hline
\end{tabular}

${ }^{\mathrm{a}}$ From crystals of $\mathbf{1 b}$ only. ${ }^{\mathrm{b}}$ From crystals of $\mathbf{1 b}$-acetone solvate.

\section{References}

(1) Dol, G. C.; Kamer, P. C. J.; van Leeuwen, P. W. N. M. Eur. J. Org. Chem. 1998, 359.

(2) Hopff, H.; Doswald, P.; Manukian, B. K. Helv. Chim. Acta 1961, 44, 1231.

(3) A. P. Bisson, C. A. Hunter, J. C. Morales and K. Young, Chem. Eur. J., 1998, 4, 845.

(4) Job, P. Ann. Chim. 1928, 9, 113. 